\title{
PEMBERDAYAAN PEREMPUAN MELALUI PELATIHAN KEWIRAUSAHAAN BERBASIS POTENSI ALAM SETEMPAT
}

\author{
Lilis Karwati \\ email : liliskarwati@gmail.com \\ Universitas Siliwangi Tasikmalaya
}

\begin{abstract}
Abstrak : Keterbatasan kemampuan perempuan merupakan permasalahan sangat krusial yang terjadi di lingkungan masyarakat terutama masalah tuntutan hidup antara kebutuhan dengan masih rendahnya kemampuan dan kecakapan yang dimiliki. Prioritas utama dalam upaya meningkatkan kualitas hidup dilakukan dalam program pemberdayaan perempuan melalui pelatihan kewirausahaan pada kelompok perempuan kurang beruntung melalui pemanfaatan potensi alam setempat yang ada di lingkungan. Penelitian ini bertujuan untuk mendeskripsikan proses, hasil, dan dampak pemberdayaan perempuan melalui pelatihan kewirausahaan. Dengan menggunakan pendekatan kuantitatif kualitatif dan metode deskriptif, penelitian ini dilaksanakan di LKP Yuniza Desa Neglasari Kecamatan Salawu bulan Agustus tahun 2016. Data dikumpulkan dengan teknik observasi partisipatif, wawancara, dan studi dokumentasi. Subjek penelitian adalah warga belajar, tutor, dan pengelola LKP Yuniza. Hasil penelitian ini menunjukkan, perempuan dapat diberdayakan melalui pelatihan kewirausahaan yang memberikan pengetahuan, sikap, keterampilan yang mampu menjadikan mereka mandiri dan dapat meningkatkan kualitas hidupnya.
\end{abstract}

Kata-kata kunci : pemberdayaan perempuan, pelatihan dan kewirausahaan

\section{WOMAN EMPOWERMENT THROUGH ENTREPRENEURS TRAINING BASED ON LOCAL NATURAL RESOURCES}

\begin{abstract}
The limited ability of women is a very crucial problem in the community, especially in fulfilling their daily needs due to the gap between the required ability and the low the ability they have. The main priority in improving the women's life quality is by providing that can improve their ability to utilize the local natural resources for commercial purposes. The purpose of this study is to describe the process, outcome and effects of the training. Applying quantitative and qualitative approach and descriptive method, this study was conducted in LKP Yuniza Desa, Kecamatan Salawu in August 2016. The data was collected by using participative observation, interview, and document study. Research subjects included learning community members, tutors, and LKP's management. The result of the study indicate women can be empowered through enterpreneurship training which provide them with knowledge, attitude, and skills enabling them independent and self employed to improve their life quality.
\end{abstract}

Keywords: woman empowerment, training, entrepreneurship

\section{PENDAHULUAN}

Perempuan merupakan salah satu komponen yang ada di masyarakat yang bisa dilibatkan dalam pembangunan. Potensi kaum perempuan dalam kehidupan masyarakat masih belum mendapat porsi yang wajar. Hal ini perlu disikapi secara arif dan bijaksana oleh pemerintah mengingat kaum perempuan dari sisi kuantitas menempati urutan pertama dari komposisi warga masyarakat. Perempuan sebagai warga negara yang memiliki hak dan kewajiban yang sama dengan laki-laki, namun dalam bidang pendidikan dan ekonomi, banyak perempuan Indonesia yang tidak memiliki kemampuan memperoleh peluang kerja karena keterbatasan atau tidak bisa mengolah potensi yang ada pada dirinya maka perlunya pemberdayaan perempuan.

Pemberdayaan adalah merupakan salah satu wadah yang dijadikan sebagai upaya untuk memberikan wahana bagi masyarakat dalam memenuhi akan kebutuhan warga belajar berupa 
pengetahuan dan keterampilan yang berkaitan bagi kehidupan yang lebih baik di dalam kehidupan keluarga dan masyarakat. Konsep pemberdayaan merupakan suatu upaya untuk menjadikan sesuatu yang adil dan beradab menjadi lebih efektif dalam seluruh aspek kehidupan. Pemberdayaan perempuan melalui pelatihan berwirausaha merupakan suatu pembelajaran dalam upaya meningkatkan pengetahuan, dan keterampilan perempuan. Kegiatan pelatihan kewirausahaan diharapkan berdampak pada kemampuan/keberdayaan perempuan menciptakan lapangan kerja. Melalui pelatihan kewirausahaan dalam memanfaatkan potensi alam yang berada di lingkungan setempat, perempuan dapat meningkatkan kesejahteraan hidupnya.

Pelatihan kewirausahaan merupakan suatu langkah penting dan perlu dilakukan dalam rangka membentuk/ mencetak sumber daya manusia yang berkualitas. Tujuan akhir yang ingin dicapai yaitu program pelatihan ini akan berdampak dalam meningkatkan keterampilan bidang usaha dan mempunyai sikap jiwa kewirausahaan dan diharapkan akan mampu menciptakan kemandirian baik dalam sikap maupun dalam berusaha. Program pelatihan kewirausahaan bertujuan agar perempuan mempunyai peningkatan dalam hal pengetahuan, keterampilan, dan sikap, sehingga dapat mengaplikasikan hasil belajarnya dalam pengelolaan usaha yang ditandai dengan melakukan wirausaha melalui pemanfaatan potensi sumber daya alam yang ada di lingkungan.

Keberhasilan penyelenggaraan program pelatihan kewirausahaan ini sangat ditentukan oleh kesadaran kelompok perempuan yang memerlukan peningkatan kemampuan berusaha dan keterampilan dirinya dalam memanfaatkan sumber potensi alam agar dapat mengolah dan memasarkan berbagai macam jenis hal-hal di bidang tata boga sehingga diharapkan peserta mampu mengaplikasikan hasil belajarnya yang ditandai dengan adanya perubahan taraf hidup yang mencakup memperoleh pekerjaan/ menciptakan lapangan kerja atau berwirausaha, peningkatan pendapatan, ekonomi, percaya diri dan mengikutsertakan orang lain dalam pemanfaatan hasil belajarnya dan berperan serta dalam kegiatan sosial dan pembangunan masyarakat. Dalam kegiatan pelatihan usaha masih terdapat berbagai permasalahan sehingga tidak semua peserta pelatihan dapat melakukan kegiatan usaha dan juga maasih ada usaha peserta yang sedang berkembang atau kurang berkembang.

Salah satu usaha yang dapat dikatakan sebagai jawaban permasalahan di atas adalah dengan mendirikan berbagai lembaga pelatihan dan keterampilan kerja. Atmodiwirio (2002:35) mendefinisikan pelatihan sebagai pembelajaran yang dipersiapkan agar pelaksanaan pekerjaan sekarang meningkat. Dalam hal ini, peranan pemerintah daerah dalam meningkatkan perekonomian dan ketenagakerjaan wanita adalah mengembangkan ketenagakerjaan secara mandiri dan terpadu yang diarahkan terutama pemberdayaan perempuan untuk peningkatan kompetensi dan kemandirian tenaga kerja, peningkatan upah pekerja, menjamin kesejahteraan, perlindungan kerja dan kebebasan berserikat, serta melakukan berbagai upaya terpadu untuk mempercepat proses pengentasan masyarakat dari kemiskinan dan mengurangi pengangguran yang merupakan dampak krisis ekonomi.

Berdasarkan permasalahan di atas maka peranan pemerintah daerah dalam meningkatkan pemberdayaan perempuan dilakukan berdasarkan program pembangunan nasional (PROPENAS) tahun 2000-2004 dalam Undang-undang Nomor 25 Tahun 2000 Bab VIII butir 3 adalah: (1) meningkatkan kedudukan dan peran perempuan dalam kehidupan berbangsa dan bernegara melalui kebijakan nasional yang diemban oleh lembaga yang mampu memperjuangkan terwujudnya kesetaraan dan keadilan gender, (2) meningkatkan kualitas peran dan kemandirian organisasi perempuan dengan tetap mempertahankan nilai persatuan dan kesatuan, (3) meningkatkan nilai histories perjuangan kaum perempuan dalam rangka melanjutkan usaha pemberdayaan perempuan serta kesejahteraan keluarga.

Hal ini sesuai dengan Undang-undang Republik Indonesia Nomor 20 Tahun 2003 tentang Sistem Pendidikan Nasional Bab VI bagian kelima pasal 26 ayat 2 dan 5 bahwa : "..(2) Pendidikan nonformal berfungsi mengembangkan potensi peserta didik dengan penekanan pada penguasaan pengetahuan dan keterampilan fungsional serta pengembangan sikap dan kepribadian profesional. (5) Kursus dan pelatihan diselenggarakan bagi masyarakat yang memerlukan bekal pengetahuan, keterampilan, kecakapan hidup dan sikap untuk mengembangkan diri, mengembangkan profesi, bekerja, usaha mandiri dan atau melanjutkan 
pendidikan ke jenjang yang lebih tinggi."

Kegiatan pelatihan kewirausahaan berbasis pada potensi alam setempat di Desa Neglasari banyak memiliki potensi sumber daya alam antara lain pertanian, perkebunan, kehutanan, perikanan dan lain-lain. Akan tetapi, masyarakat belum optimal dalam memanfaatkan sumber daya alam tersebut. Melalui layanan pendidikan nonformal, keterampilan dan kecakapan masyarakat dapat ditingkatkan sehingga dapat memanfaatkan potensi sumber daya alam di Desa Neglasari secara optimal.

Lembaga Kursus dan Pelatihan Yuniza melaksanakan pendidikan keterampilan berwirausaha memberdayakan perempuan/para ibu rumah tangga melalui pelatihan membuat berbagai macam produk makanan minuman yang memanfaatkan potensi alam setempat. Berdasarkan hasil di lapangan, peneliti merasa tertarik untuk meneliti lebih dalam bagaimana proses pemberdayaan perempuan itu berlangsung melalui pendidikan keterampilan yang berbasis pada potensi alam setempat, dampaknya serta bagaimana hasil pemberdayaan perempuan itu dapat tercapai agar pada akhirnya meningkatkan taraf hidup masyarakat.

Mengacu pada latar belakang yang telah diuraikan, masalah penelitian ini dirumuskan, "Bagaimana gambaran proses dan hasil pemberdayaan perempuan melalui pelatihan kewirausahaan berbasis potensi alam setempat LKP Yuniza?" Dengan melihat keterbatasan dan kemampuan yang penulis miliki, terlalu luasnya permasalahan yang ada dan untuk menghindari salah penafsiran masalah tersebut, maka masalah penelitian dibatasi sebagai berikut: (1) bagaimana proses pemberdayaan perempuan melalui pelatihan kewirausahaan berbasis potensi alam setempat yang diselenggarakan LKP Yuniza? (2) bagaimana hasil yang dicapai dari pemberdayaan perempuan melalui pelatihan kewirausahaan berbasis potensi alam setempat yang diselenggarakan di LKP Yuniza? dan (3) bagaimana dampak dari pemberdayaan perempuan melalui pelatihan kewirausahaan berbasis potensi alam setempat yang diselenggarakan di LKP Yuniza?

Tujuan penelitian ini adalah untuk mendapatkan jawaban tentang masalah yang dirumuskan, yaitu (a) menganalisis proses pemberdayaan perempuan melalui pelatihan kewirausahaan berbasis potensi alam setempat di LKP Yuniza, (b) mendeskripsikan hasil dari proses pemberdayaan perempuan melalui pelatihan kewirausahaan berbasis potensi alam setempat di LKP Yuniza, (c) mengimplementasikan dampak dari proses pemberdayaan perempuan melalui pelatihan kewirausahaan berbasis potensi alam setempat di LKP Yuniza.

Adapun kegunaan penelitian ini adalah (1) secara konseptual, dapat memperkaya konsep pendidikan, pemberdayaan perempuan, dan Pendidikan Luar Sekolah, (2) secara praktis, bagi semua penyelenggara program pemberdayaan perempuan dan pelatihan serta para tutor bisa lebih meningkatkan kualitas penyelenggaraan program dan penyelenggara mampu memfasilitasi dan mendorong pelaksanaan program pemberdayaan perempuan melalui pelatihan kewirausahaan.

Pemberdayaan perempuan dan pelatihan kewirausaahaan adalah termasuk ke dalam salah satu ruang lingkup Pendidikan Luar Sekolah. Usaha pemberdayaan perempuan melalui peningkatan dan pembinaan kecakapan hidup pada saat sekarang ini semakin memerlukan perhatian dan penanganan yang benar-benar tepat guna dan hasil guna. Salah satu usaha yang dapat dikatakan sebagai jawaban permasalahan di atas adalah dengan mendirikan berbagai lembaga pelatihan dan keterampilan kerja sebagai bentuk layanan pendidikan nonformal .

Kindervatter dalam Kamil (2009: 54) menjelaskan peran pendidikan nonformal dalam proses pemberdayaan mengandung arti luas yakni mencakup meningkatkan pengetahuan, sikap, keterampilan dan pengembangan lainnya ke arah kemandirian hidup dan di dalamnya juga meliputi peningkatan dan perubahan sumber daya manusia sehingga mampu membangun masyarakat dan lingkungannya. Perempuan/para ibu rumah tangga dapat dibina dan diberdayakan sehingga mereka dapat memainkan peran gandanya yaitu sebagai pengurus keluarga, membantu perekonomian keluarga, dan sebagai pelaku pembangunan

Atmodiwirio (2002:37) mengemukakan, "Pelatihan adalah proses kegiatan pembelajaran antara pengalaman untuk mengembangkan pola perilaku seseorang dalam bidang pengetahuan, keterampilan, atau sikap untuk mencapai standar yang diharapkan". Dengan demikian, pelatihan adalah proses merekayasa perilaku pesrta didik dalam aspek pengetahuan, sikap dan keterampilan untuk meningkatkan keterampilan dalam upaya memenuhi kebutuhan hidup.

Manfaat yang diperoleh dari pelatihan 
yang diadakan oleh perusahaan seperti yang dinyatakan oleh Eka (2010) adalah (1) programprogram pengembangan yang direncanakan akan memberikan manfaat kepada orang berupa peningkatan produktivitas, peningkatan moral, pengurangan biaya, dan stabilitas serta keluwesan (fleksibilitas); (2) program membantu dalam memenuhi kebutuhan perorangan untuk mencari pekerjaan yang bermakna bagi karir seumur hidup.

Suryana (2003:1) menyebutkan, "Kewirausahaan adalah kemampuan kreatif dan inovatif yang dijadikan dasar, kiat, dan sumber daya untuk mencari peluang menuju sukses. Inti dari kewirausahaan adalah kemampuan untuk menciptakan sesuatu yang baru dan berbeda melalui berpikir kreatif dan bertindak inovatif untuk menciptakan peluang". Sedangkan Kristanto (2009:2) berpendapat, kewirausahaan dan inovasi merupakan hal sentral dalam proses kreatif perekonomian. Inovasi adalah fungsi spesifik dari kewirausahaan, sebagai sebuah cara menciptakan sumber daya baru yang mendayagunakan sumberdaya yang ada untuk menghasilkan kekayaan.

Ada beberapa faktor yang mempengaruhi perilaku kewirausahaan yaitu (1) keuletan, syarat untuk mencapai tujuan yang merupakan sumber keberhasilan usaha dengan modal kerja fisik dan akal, kita harus ulet dan mampu memulai usaha. Tohar (2000:173) mendefinisikan keuletan adalah "Merupakan sinar terang keberhasilan dalam menjalankan kehidupan manusia dalam pengertian diri sendiri, keluarga atau lingkungan yang lebih luas lagi. Orang ulet tidak mudah putus asa, dan juga selalu yakin bahwa kegagalan adalah guru tebaik untuk maju, kegagalan harus dihadapi dengan sikap objektif yaitu bebas dari perasaan yang negatif." Selanjutnya M. Tohar (2000:174) juga menjelaskan, ciri orang yang ulet adalah (a) tidak mudah putus asa dan (b) apabila gagal, ia lakukan introspeksi sehingga mendorong untuk bangkit dan mempunyai tekad untuk maju. (2) kreatif dan inovatif, kreativitas merupakan sebuah proses yang dikembangkan dan ditingkatkan, namun kemampuan ini berbeda dari satu orang terhadap orang lain. Kemampuan dan bakat merupakan dasar tetapi pengetahuan dan lingkungannya dapat juga mempengaruhi kreativitas orang. Menurut Edwar be Hono (1970) yang dikutip oleh Rambat Lupiyoadi dan Jero Wecik (1998:85) ada empat tahapan dalam proses kreatif yakni (a) latar belakang atau akumulasi pengetahuan, (b) proses inkubasi, (c) melahirkan ide, serta (d) evaluasi dan implementasi.

Hal yang paling penting dalam tahap ini adalah wirausaha mencoba kembali ide-ide sampai menemukan bentuk finalnya, karena ide yang muncul biasanya dalam bentuk tidak sempurna, jadi masih perlu dimodifikasi dan diuji untuk mendapatkan bentuk yang baku dan matang dari ide tersebut

Inovatif merupakan salah satu faktor yang mempengaruhi perilaku kewirausahaan yang harus dimiliki oleh seorang wirausahawan, menurut Koentjoroningrat (1986: 258) bahwa orang yang memiliki perasaan inovatif adalah " Orang yang bersedia menerima adanya pembaharuan seprti dalam tiap masyarakat tentu ada individuinidvidu yang sadar akan adanya berbagai macam kekurangan mereka, diantaranya para individu itu ada yang berbuat sesuatu untuk mengisi atau memperbaiki kekurangan yang mereka sadari.

\section{METODE PENELITIAN}

Untuk mengetahui bagaimana pemberdayaan perempuan melalui pelatihan kewirausahaan di LKP Yuniza dilaksanakan dan hasil belajar melalui pelatihan kewirausahaan dalam pemberdayaan perempuan, metode yang dianggap paling relevan dalam penelitian ini adalah metode deskriptif. Hal ini didasarkan pada petimbangan bahwa masalah yang diteliti merupakan masalah yang ada pada masa sekarang (aktual) atau merupakan gejala-gejala yang nampak dewasa ini, sehingga pemecahannya pun dapat dilakukan berdasarkan data yang diperoleh, dinalisis dan kemudian dikembangkan cara pemecahannya. Penelitian deskriptif yang bersipat eksploratif bertujuan untuk menggambarkan keadaan atau status fenomena.

Data dikumpulkan dari 58 peserta pelatihan dengan menggunakan angket, yang kemudian diolah dan dianalisis secara statistic untuk mengambil kesimpulan. 


\section{HASIL DAN PEMBAHASAN}

\section{Proses Pemberdayaan Perempuan Melalui Pelatihan Kewirausahaan}

Berdasarkan hasil penelitian maka diperoleh nilai dari 30 kuesioner yang dibagikan kepada responden sebanyak 58 orang maka diperoleh hasil sebagai berikut.

Tabel 1

Distribusi Frekuensi Variabel Proses Pemberdayaan

\begin{tabular}{llllll}
\hline Kelompok & $\begin{array}{l}\text { Rata- } \\
\text { rata }\end{array}$ & Median & $\begin{array}{l}\text { Standar } \\
\text { Deviasi }\end{array}$ & $\begin{array}{l}\text { Nilai } \\
\text { Min }\end{array}$ & $\begin{array}{l}\text { Nilai } \\
\text { Maks }\end{array}$ \\
\hline Pemberdayaan & 98.67 & 1.00 & 13.44 & 72 & 122 \\
\hline
\end{tabular}

Untuk mengetahui kategori dari data Tabel 1 , selanjutnya penulis membandingkan antara nilai rata-rata dengan skor minimum ditambah dengan standar deviasi, dengan pedoman yaitu (a) jika (mean) > skor min + 4 SD (standar deviasi) = sangat tinggi; (b) jika (mean) > skor min + 3 SD (standar deviasi $)=$ tinggi; $($ c) jika $\quad($ mean $)>$ skor min +2 SD (standar deviasi) = cukup; (d) ika $\quad($ mean $)<$ skor $\min +2$ SD (standar deviasi) $=$ rendah .

Berdasarkan pedoman tersebut di atas maka proses pemberdayaan perempuan termasuk ke dalam kategori rendah.

Tabel 2

Pangkategorian Data Proses Pemberdayaan Melalui Pelatihan di LKP Yuniza Tasikmalaya

\begin{tabular}{lclll}
\hline No. & & Rentang kkor & Kategori & Harga \\
\hline 1. & Jika & (mean) $>$ skor min + 4 SD & Sangat & 125,76 \\
& & & Tinggi & \\
2. & Jika & (mean) $>$ skor min + 3 SD & Tinggi & 112,32 \\
3. & Jika & (mean) $>$ skor min + 2 SD & Cukup & 98,88 \\
4. & Jika & (mean) $<$ skor min + 2 SD & Rendah & 98,88 \\
\hline
\end{tabular}

Selanjutnya apabila hasil analisis SPSS 17 maka histogram untuk pemberdayaan dapat disajikan dalam Gambar 1 di bawah ini.

Histogram

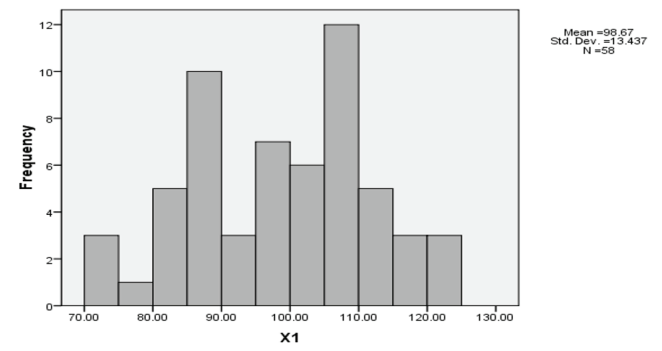

Gambar 1. Histogram proses pemberdayaan perempuan
Berdasarkan data dalam Tabel 2 diketahui bahwa rata-rata Pemberdayaan pelatihan kewirausahaan yang sasaranya perempuan dapat dikategorikan rendah hal ini dikarenakan nilai mean $98.67>98.88$. Dikategorikan rendah hal ini dikarenakan nilai mean $98.67>98.88$. dikarenakan belum adanya kegiatan program pelatihan.

\section{Hasil yang Dicapai dari Pemberdayaan Perempuan Melalui Pelatihan Kewirausahaan}

Berdasarkan hasil penelitian maka diperoleh nilai kuesioner untuk pemberdayaan perempuan sebanyak 58 orang maka diperoleh hasil: nilai tertinggi diperoleh sebesar 121 dan nilai terendah sebesar 66 dengan rentang nilai (range) sebesar 55 mean sebesar 96.02. median sebesar 97.50 dan standar deviasi diperoleh sebesar 13.58 . Selanjutnya dari data tersebut disusun dalam bentuk distribusi frekuensi yang disajikan pada Tabel 3 berikut.

Tabel 3

Distribusi Frekuensi Variabel Pemberdayaan Perempuan Melalui Pelatihan

\begin{tabular}{llllll}
\hline Kelompok & Rata-rata & Median & $\begin{array}{l}\text { Standar } \\
\text { deviasi }\end{array}$ & $\begin{array}{l}\text { Nilai } \\
\text { min }\end{array}$ & $\begin{array}{l}\text { Nilai } \\
\text { maks }\end{array}$ \\
\hline Pelatihan & 96.02 & 97.50 & 13.58 & 66 & 121 \\
\hline
\end{tabular}

Untuk mengetahui kategori dari data Tabel 3 , selanjutnya penulis membandingkan antara nilai rata-rata dengan skor minimum ditambah dengan standar deviasi, dengan pedoman sebagai berikut (a) jika (mean) > skor min + 4 SD (standar deviasi) = sangat tinggi; (b) jika (mean) > skor min + 3 SD (standar deviasi) $=$ tinggi; (c) jika $($ mean $)>$ skor min + 2 SD (standar deviasi) = cukup; (d) jika (mean) < skor min + 2 SD (standar deviasi) = rendah .

Berdasarkan pedoman tersebut di atas maka Hasil pemberdayaan perempuan melalui pelatihan kewirausahaan termasuk ke dalam kategori cukup, hal ini dikarenakan (mean) > skor min + 2 SD (standar deviasi). Adapun distribusi frekuensi dari hasil pemberdayaan perempuan melalui pelatihan kewirausahaan 
Tabel 4

Pangkategorian Data Pemberdayaan Perempuan Melalui Pelatihan Kewirausahaan

\begin{tabular}{|c|c|c|c|c|}
\hline No. & & Rentang skor & Kategori & Harga \\
\hline 1. & Jika & $($ mean $)>$ skor $\min +4 \mathrm{SD}$ & $\begin{array}{l}\text { Sangat } \\
\text { Tinggi }\end{array}$ & 120,32 \\
\hline 2. & Jika & $($ mean $)>$ skor $\min +3 \mathrm{SD}$ & Tinggi & 106,74 \\
\hline 3. & Jika & $($ mean $)>$ skor $\min +2 \mathrm{SD}$ & Cukup & 93,16 \\
\hline 4. & Jika & $($ mean $)<$ skor $\min +2 \mathrm{SD}$ & Rendah & 93,16 \\
\hline
\end{tabular}

Berdasarkan data dalam Tabel 4 diketahui bahwa rata-rata hasil pemberdayaan perempuan melalui pelatihan kewirausahaan dapat dikategorikan tinggi hal ini dikarenakan nilai mean $96.02>93.16$.

Selanjutnya apabila hasil analisis SPSS 17 maka histogram untuk hasil pemberdayaan perempuan melalui pelatihan kewirausahaan dapat disajikan dalam Gambar 2 di bawah ini.

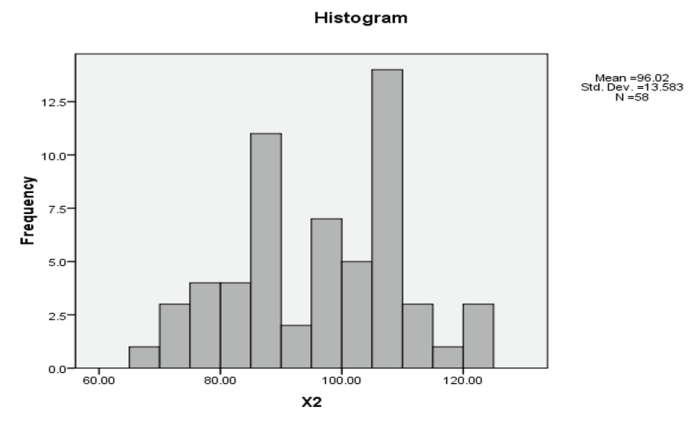

Gambar 2. Histogram hasil pemberdayaan perempuan melalui pelatihan kewirausahaan

Berdasarkan data tersebut di atas, menunjukkan bahwa hasil pemberdayaan perempuan melalui pelatihan kewirausahaan termasuk dalam kategori cukup. Hal ini dikarenakan kelompok perempuan telah berupaya untuk selalu aktif mengikuti pelatihan kewirausahaan meskipun masih belum memahami sepenuhnya tentang praktik kegiatan kewirausahaan.

\section{Dampak dari Pemberdayaan Perempuan Melalui Pelatihan Kewirausahaan}

Berdasarkan hasil penelitian maka diperoleh bahwa dampak dari pemberdayaan perempuan melalui pelatihan kewirausahaan dari 58 orang diperoleh hasil: nilai tertinggi diperoleh sebesar 124 dan nilai terendah sebesar 74 dengan rentang nilai (range) sebesar 50 mean sebesar 99.89. Median sebesar 10.10 dan standar deviasi diperoleh sebesar 13.26. Selanjutnya dari data tersebut disusun dalam bentuk distribusi frekuensi yang disajikan pada Tabel 5 berikut ini.

Tabel 5

Distribusi Frekuensi Variabel Dampak dari Pemberdayaan Perempuan Melalui Pelatihan Kewirausahaan

\begin{tabular}{llllll}
\hline Kelompok & $\begin{array}{l}\text { Rata- } \\
\text { rata }\end{array}$ & Median & $\begin{array}{l}\text { Standar } \\
\text { Deviasi }\end{array}$ & $\begin{array}{l}\text { Nilai } \\
\text { Min }\end{array}$ & $\begin{array}{l}\text { Nilai } \\
\text { Maks }\end{array}$ \\
\hline $\begin{array}{l}\text { Pemberdayaan } \\
\text { Pelatihan }\end{array}$ & 99.89 & 10.10 & 13.26 & 74 & 124 \\
\hline
\end{tabular}

Untuk mengetahui kategori dari data Tabel 5 , selanjutnya penulis membandingkan antara nilai rata-rata dengan skor minimum ditambah dengan standar deviasi, dengan pedoman yaitu (a) jika (mean) > skor min + 4 SD (standar deviasi) = sangat tinggi; (b) jika (mean) > skor min + 3 SD (standar deviasi) = tinggi; $($ c) jika $($ mean $)>$ skor $\min +2$ SD (standar deviasi) $=$ cukup; $(\mathrm{d})$ jika $\quad($ mean $)<$ skor $\min +2 \mathrm{SD}$ (standar deviasi) = rendah .

Berdasarkan pedoman tersebut di atas maka dampak dari pemberdayaan perempuan melalui pelatihan kewirausahaan termasuk ke dalam kategori rendah, hal ini dikarenakan $($ mean) $<$ skor min +2 SD (standar deviasi). Adapun distribusi frekuensi dari dampak dari pemberdayaan perempuan melalui pelatihan kewirausahaan selengkapnya dapat dilihat pada Tabel 6 berikut ini.

Tabel 6

Pengkategorian Data pemberdayaan Perempuan Melalui Pelatihan Kewirausahaan

\begin{tabular}{cclll}
\hline No. & Rentang skor & Kategori & Harga \\
\hline 1 & Jika & (mean) $>$ skor min + 4 SD & $\begin{array}{l}\text { Sangat } \\
\text { Tinggi }\end{array}$ & 127,04 \\
2 & Jika & (mean) $>$ skor min + 3 SD & Tinggi & 113,78 \\
3 & Jika & (mean) $>$ skor min + 2 SD & Cukup & 100,52 \\
4 & Jika & (mean) $<$ skor min + 2 SD & Rendah & 100,52 \\
\hline
\end{tabular}

Berdasarkan data dalam Tabel 6, diketahui bahwa rata-rata dampak dari pemberdayaan perempuan melalui pelatihan kewirausahaan dapat dikategorikan rendah hal ini dikarenakan nilai mean $99.89<100.52$. Selanjutnya apabila hasil analisis SPSS 17 maka histogram untuk dampak dari pemberdayaan perempuan melalui pelatihan kewirausahaan dapat disajikan dalam Gambar 3 di bawah ini. 


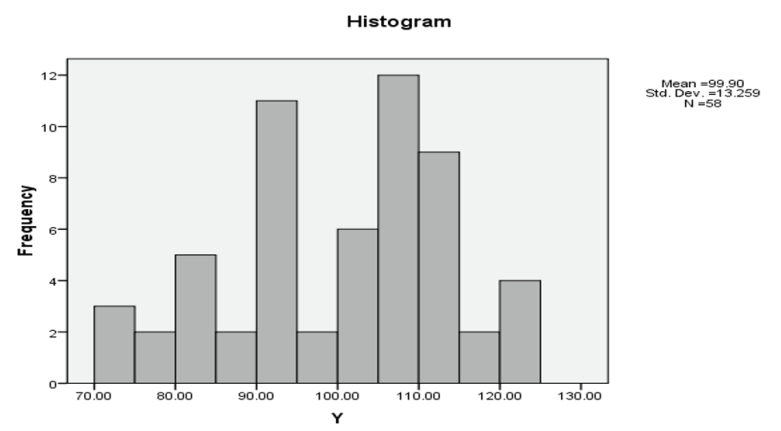

Gambar 3. Histogram dampak dari pemberdayaan perempuan melalui pelatihan kewirausahaan

Berdasarkan data tersebut di atas, menunjukkan bahwa dampak dari pemberdayaan perempuan melalui pelatihan kewirausahaan masih rendah sehingga perlu peningkatan kesadaran para perempuan untuk berdaya. Adanya partisipasi dari berbagai pemerintah serta pendampingan dari lembaga lembaga masyarakat di bidang pendidikan non formal dalam membantu perempuan juga adanya keinginan dalam dirinya untuk berdaya dan memiliki kemauan dan kemampuan untuk terus belajar dengan pelaksanaan program yang harus disesuaikan antara tuntutan masyarakat dengan kebutuhan serta perlu tersedianya sarana prasarana yang memadai.

\section{Proses proses pemberdayaan perempuan melalui pelatihan kewirausahaan}

Berdasarkan deskripsi hasil penelitian dan hasil fakta bahwa bahwa ada adanya dampak dari hasil kegiatan pemberdayaan perempuan melalui pelatihan kewirausahaan berbasis potensi alam setempat terhadap pemberdayaan dalam melaksanakan kegiatan pelatihan apabila dilaksanakan secara efektif maka pelaksanaan kegiatan akan berjalan semakin baik.

Pemberdayaan perempuan akan berpengaruh terhadap keadaan sosial ekonomi dan partisipasi perempuan terhadap pelaksanaan kegiatan pelatihan, dengan keadaan sosial ekomoni yang rendah masyarakat cenderung bersikap pasif dan menunnggu. Hal ini disebabkan karena wawasan mereka yang terbatas.perlu adanya pembelajaran bagi perempuan ,untuk meningkatkan pengetahuan keterampilan dan sikap dalam menjalankan dan memanfaatkan potensi sumber daya alam yang ada dilingkungan setempat. Dengan itu partisipasi merupakan katalisator untuk melaksanakan pemeliharaan selanjutnya yang mendorong timbulnya tanggung jawab, sehingga terjadi perpaduan berbagai keahlian pekerjaan yang dilaksanakan dengan arah yang benar, membebaskan orang dari ketergantungan kepada keahlian orang lain serta lebih menyadarkan manusia terhadap penyebab kemiskinan sehingga menimbulkan kesadaran usaha untuk mengatasinya.

Hasil yang dicapai dari pemberdayaan perempuan melalui pelatihan kewirausahaan

Berdasarkan hasil penelitian diketahui bahwa ada hubungan antara hasil yang dicapai dari pemberdayaan perempuan dengan pelatihan kewirausahaan hubungan tersebut hakikatnya merupakan satu bangunan saling menguatkan karena manusia tergantung pada lingkungan. Sedangkan lingkungan sangat tergantung pada aktifitas manusia. Namun dilihat dari sisi manusia maka lingkungan adalah sesuatu yang pasif, dan manusia adalah sesuatu yang aktif, sehingga kualitas lingkungan tergantung pada kualitas manusia. Seseorang bersikap sesuatu karena ada masukan pengetahuan tertentu. Pengetahuan mengenai suatu objek baru menjadi sikap terhadap objek tersebut apabila pengetahuan itu disertai oleh kesiapan untuk bertindak sesuai dengan pengetahuan terhadap objek itu. Dari uraian di atas, maka dapat digarisbawahi bahwa hasil yang dicapai dari pemberdayaan perempuan perlu adanya kesadaran, tanggung jawab.

Dampak dari pemberdayaan perempuan melalui pelatihan kewirausahaan berbasis potensi alam setempat

Berdasarkan analisis angket, dampak dari pelaksanaan pemberdayaan dampaknya adalah adanya peningkatan pendapatan dengan memanfaatkan potensi yang ada di lingkuungan mereka menjadi memiliki penghasilan serta para warga belajar memiliki pengetahuan dan keterampilan baru yang sebelumnya belum pernah mereka dapatkan dengan tujuan untuk memperbaiki kualitas hidup dan meningkatkan taraf kehidupannya meskipun mereka hanya sebagian kelompok belajar yang memiliki kecakapan memperoleh pengetahuan, keterampilan, sikap kepercayan diri yang meningkat, lebih terdidik serta mendapatkan pengalaman baru, yang lebih utama warga belajar memperoleh pendapatan yang sebelumnya tidak memiliki penghasilan untuk mencukupi kebutuhan seharihari, namun hal ini dapat membantu perekonomian keluarga. Selain itu sikap kemandirian, kreatif sesama warga belajar ataupun dengan tutor. 


\section{PENUTUP}

\section{Kesimpulan}

Pemberdayaan perempuan melalui kewirausahaan berbasis potensi alam setempat merupakan salah satu wadah yang dijadikan sebagai upaya untuk memberikan wahana bagi perempuan dalam memenuhi akan kebutuhan warga belajar berupa pengetahuan dan keterampilan yang berkaitan bagi kehidupan sehingga warga belajar lebih siap menghadapi persaingan di era globalisasi yang disebabkan meningkatnya kualitas sumber daya manusia. Salah satu upaya dalam memberikan layanan membuat program pemberdayaan perempuan melalui pelatihan dengan memanfaatkan sumber daya alam yang tersedia dilingkunganya dalam bidang tata dengan sasarannya Ibu rumah tangga yang tidak memiliki pengetahuan dan keterampilan yang cukup, dengan tujuan memberdayakan perempuan agar mampu memiliki pengetahuan serta keterampilan yang pada akhirnya dapat meningkatkan kualitas hidup. Hasil yang diperoleh oleh warga belajar lebih menitik beratkan pada aspek kemampuan keterampilan dalam meningkatkan pendapatan warga belajar dapat memanfaatkan waktu luang dengan melakukan kegiatan dan dapat bersosialisasi berinteraksi dan bertukar pengalaman dan dapat mengembangkan usaha dari hasil kegiatan yang telah dilaksanakan.

\section{Saran}

Perlu adanya kemitraan yang lebih baik lagi dengan berbagai lembaga pemerintah dan swasta terutama bantuan sarana dan prasarana sekaligus sebagai bapak angkat dalam pelaksanaan pendampingan. Perlu mendirikan outlet untuk menampung berbagai produk yang dihasilkan oleh warga belajar dalam mengembangkan kegiatan usaha

\section{DAFTAR PUSTAKA}

Arikunto, S. (2010). Prosedur penelitian: Suatu pendekatan praktek. Jakarta : PT Rineka Cipta.

Atmodiwirio, S. (2002). Manajemen pelatihan. Jakarta: Ardadizya Jaya.

Bygrave, W.D. (1996) Enterprenership. Jakarta : Bina Aksara

Eka. (2010). Pelatihan tenaga kerja: Definisi, tujuan, manfaat dan metode pelatihan kerja. Diakses dari http://jurnal-sdm.blogspot.co.id/2010/11/ pelatihan-tenaga-kerja-definisi-tujuan_11.html

Kamil, M. (2009). Pendidikan nonformal: Pengembangan melalui Pusat Kegiatan Belajar Masyarakat (PKBM) di Indonesia (Sebuah pembelajaran dari kominkan Jepang). Bandung: Alfabeta.

Kindervatter, S. (1979). Non-formal education as an empowering process. Amherst: Centre for International and Education.

Koentjoroningrat. (1986). Pengantar ilmu Antopologi.
Jakarta : Rineka Cipta

Kristanto, R. H. (2009). Kewirausahaan (entrepreneurship) pendekatan manajemen dan praktik. Yogyakarta: Graha IImu.

Meredith, G., et, al, (2002). Kewirausahaan, teori dan praktek. Jakarta : Penerbit PPM

Suryana, Dr. (2003). Kewirausahaan pedoman praktis, kiat dan proses menuju sukses. Jakarta : Salemba Empat.

Suwanto. (2008). Manajemen sumber daya manusia. Bandung: Pasca Sarjana UPI \& ALFABETA.

Tohar, M. (2000). Membuka usaha kecil. Yogyakarta: Kanisius.

Undang-Undang Republik Indonesia Nomor 20 Tahun 2003 Tentang Sistem Pendidikan Nasional. Jakarta : Cipta Jaya

Undang-Undang (UU) Nomor 22 Tahun 1999 tentang Pemerintahan Daerah.

Wacik, J. \& Lupiyoadi, R. (1998). Wawasan kewirausahaan. Jakarta: LPFEU. 